\title{
Influence of management on maintenance and dynamics of carbon in the soil
}

\begin{abstract}
This work aimed to analyze the dynamics of soil carbon in agricultural areas under different soil management systems and natural ecosystems with Cerrado vegetation. The study was carried out in a grain production area equivalent to soybeans and corn located in the Western region of Bahia State with the adoption of conventional and no-tillage + Brachiaria and vegetable production in the southernmost tip of Piaui State under organic cultivation and vegetable cultivation + no-tillage, besides the native area of the Cerrado. Total organic $\mathrm{C}$ content, light organic matter, and soil organic matter were evaluated. Furthermore, the $\mathrm{C}$ stock and light organic matter were assessed at four depths $(0.0-0.05,0.05-0.10,0.10-0,20$, and $0.20-0.40 \mathrm{~m})$. The systems under vegetable cultivation and native area presented the highest levels of C, organic matter, and soil carbon stocks in the superficial layers. However, the NTS + B2 showed higher levels in depth, except for light organic matter. Thus, the content, dynamics, and maintenance of $C$ into the soil are nearly influenced by the management system adopted, both for the lighter fractions of organic matter and the more mineralized forms such as TOC, OSM, and StkC.
\end{abstract}

Keywords: Conservation management; No-tillage; Soil organic matter.

\section{Influência do manejo na manutenção e dinâmica do carbono no solo}

O objetivo destetrabalho foianalisar a dinâmica do carbono do solo em áreas agrícolas sob diferentes sistemas de manejo do solo e ecossistema natural com vegetação do Cerrado. O estudo foi realizado em área de produção de grãos equivalente a soja e milhosituada no Oeste Baiano com adoção de plantio convencional e plantio direto + Brachiaria e produção de hortaliças no Extremo Sul Piauiense sob cultivo orgânico ecultivo de hortaliça + Plantio Direto, além de área nativa do Cerrado. Foram avaliados o conteúdo de $\mathrm{C}$ orgânico total, matéria orgânica leve e do solo, também se avaliouo estoque de $\mathrm{C}$ e da matéria orgânica leve em quatro profundidades $(0,0-0,05,0,05-0,10,0,10-0,20$ e 0,20-0,40 m). Em geral, os sistemas sob cultivo de hortaliças e área nativa obtiveram os maiores teores de estoque de C, matéria orgânica e carbono solo nas camadas superficiais enquanto o NTS+B2 apresentou maiores teores em profundidade, exceto para matéria orgânica leve. Assim, o conteúdo, dinâmica e manutenção do $C$ no solo são estreitamente influenciados pelo sistema de manejo adotado, tanto para as frações mais leves da matéria orgânica quanto para as formas mais mineralizadas como o TOC, OSM e StkC.

Palavras-chave: Manejo conservacionista; Plantio direto; Matéria orgânica do solo.

\section{Topic: Ciências do Solo}

Reviewed anonymously in the process of blind peer
Received: 02/01/2021

Approved: 25/01/2021
Tancio Gutier Ailan Costa (iD

Universidade Federal Rural do Rio de Janeiro, Brasil http://lattes.cnpq.br/9269110451831376 http://orcid.org/0000-0002-0635-2651 gutierailan@gmail.com

Bruna de Freitas Iwata (iD)

Instituto Federal do Piauí, Brasil

http://lattes.cnpq.br/3036032785449787

http://orcid.org/0000-0002-6465-9731

iwata@ifpi.edu.br

\section{Wesley dos Santos Souza (iD}

Universidade Federal Rural do Rio de Janeiro, Brasil http://lattes.cnpq.br/4286185972062563 http://orcid.org/0000-0002-5186-6627 agrowesley95@gmail.com

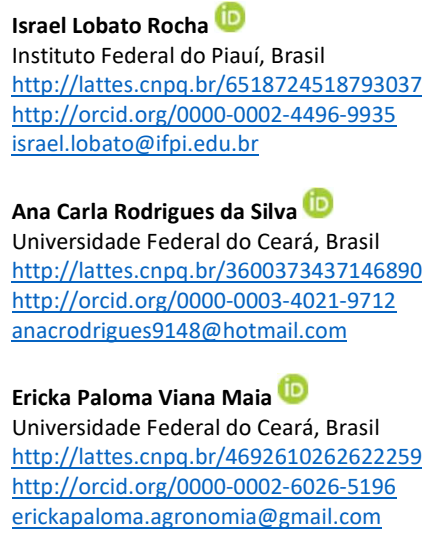

Ana Carla Rodrigues da Silva (iD

Universidade Federal do Ceará, Brasil http://lattes.cnpq.br/3600373437146890 http://orcid.org/0000-0003-4021-9712 anacrodrigues9148@hotmail.com

Ericka Paloma Viana Maia (it

Universidade Federal do Ceará, Brasil http://lattes.cnpq.br/4692610262622259 http://orcid.org/0000-0002-6026-5196 erickapaloma.agronomia@gmail.com

Paula Fernanda Alves Ferreira (D)

Universidade Federal Rural do Rio de Janeiro, Brasil http://lattes.cnpq.br/4746910588907703 http://orcid.org/0000-0001-7533-1216 paula.faf@hotmail.com

Claudio Adriano de Jesus Nascimento (iD Universidade Federal Rural do Rio de Janeiro, Brasil http://lattes.cnpq.br/3383726994014274 http://orcid.org/0000-0002-0186-2310 adriano c2@live.com

\section{Amanda Sales Alves (iD}

Universidade Federal Rural do Rio de Janeiro, Brasil http://lattes.cnpq.br/1560247986661120 http://orcid.org/0000-0001-9403-7282 amanda sales alves@hotmail.com

\section{Referencing this:}

COSTA, T. G. A.; IWATA, B. F.; SOUZA, W. S.; ROCHA, I. L.; SILVA, A. C. R.; MAIA, E. P. V.; FERREIRA, P. F. A.; NASCIMENTO, C. A. J.; ALVES, A. $S$.. Influence of management on maintenance and dynamics of carbon in the soil. Revista Ibero Americana de Ciências Ambientais, v.12, n.1, p.11-22, 2021. DOI: http://doi.org/10.6008/CBPC21796858.2021 .001 .0002

DOI: 10.6008/CBPC2179-6858.2021.001.0002 


\section{INTRODUCTION}

Soils maintained in natural ecosystems under conditions of native vegetation, have good characteristics for plant growth and development. However, as these environments are transformed into productive systems by inadequate exploitation of resources, the degradation process becomes evident. For this reason, the adoption of more conservative and low soil mobilization management systems has been sought to preserve their physical-chemical and biological characteristics, essential for the adequate development of plants, especially those that ensure a greater increase in carbon to the system.

As exposed by Leite et al. (2010) the deposition and maintenance of plant material on the soil surface and the reduction of the soil mobilization are presented as a way to increase the storage of carbon in the soil. On the other hand, the conventional management and preparation of the soil with successive soil mobilization processes by harrowing contribute to the expressive decrease in the organic matter content, compared, for example, to no-till (TEIXEIRA et al., 2010). For this reason, management that prioritizes crop rotation, green manure, production, and application of organic fertilizers, biofertilizers, and vermicompounds is essential for the preservation of organic matter in the soil.

Organic matter acts as an important pointer of soil quality, since its content in the soil allows better conditions for plant cultivation, due to improvements in its physical, chemical, and biological characteristics (VARGAS et al., 2013). In soil, its content depends on the addition of organic material, the rate of mineralization, soil texture, climate, and other factors. These maintain a relationship with each other so that the content of organic matter tends to go towards an equilibrium value in areas under native vegetation (KHORRAMDEL et al., 2013). Nevertheless, in agricultural areas, the management adopted has an influence on the stocks of organic matter, which can decrease, maintain or increase these stocks concerning native vegetation (KHORRAMDEL et al., 2013).

In this sense, it is evident that the maintenance of $\mathrm{C}$ in the soil associated with organic matter is fundamental to ensure the agricultural sustainability since higher levels of organic matter in the soil generally lead to greater crop productivity and increased efficiency of use of nutrients (PAUL et al., 2013). Thus, as Salton et al. (2011) assert, for the use of organic matter as a quality indicator agent becomes useful in the diagnosis of sustainable systems, it is essential to know in detail the mechanisms of carbon supply to the soil and its dynamics in the environment. Therefore, the work aimed to analyze the dynamics of soil carbon in agricultural areas under different soil management systems and natural ecosystems with Cerrado vegetation.

\section{MATERIALS AND METHODS}

\section{Study Area Description}

The study was conducted in areas of grain production (such as soybeans and corn), belonging to the Agricultural Cooperative of Cerrado Brazil Central (Portuguese acronym, COACERAL), in the municipality of Formosa do Rio Preto - Western of the Bahia State, and areas of vegetable production in the condition of family farming at the municipality of Corrente, in the southernmost tip of Piauí State.The region's climate is 
classified as Aw under the influence of the Tropical Savannah climate, according to Köppen's classification, with two well-defined seasons, one warm and rainy, and the other mild and dry. For the study site, in the West of Bahia State, the rainfall varies between 1000 and $1800 \mathrm{~mm}$, providing mean annual temperatures

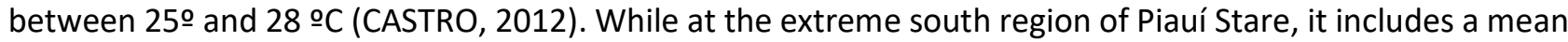
annual temperature of $25^{\circ} \mathrm{C}$, and a mean rainfall between 1000 and $1200 \mathrm{~mm}$ (ANDRADE JÚNIOR, 2004). The soils were classified as Red-Yellow Latosol and Yellow Latosol, with clay-sandy and medium texture, respectively.

The experimental design used was completely randomized (CRD) in a 5x4 split-plot arrangement (four managements, one control, and four depths), with three replications. Four soil management systems were evaluated, in addition to an adjacent area under native vegetation (Table 1). Soil sampling was made at depths of $0.0-0.05 ; 0.05-0.10 ; 0.10-0.20$, and $0.20-0.40 \mathrm{~m}$.

Table 1: Description of the management adopted in the agricultural production areas and under native vegetation of Cerrado.

\begin{tabular}{|c|c|c|}
\hline Management system & Abbreviation & Description of the soil use and management \\
\hline $\begin{array}{l}\text { Conventional Planting } \\
\text { System }\end{array}$ & CPS & $\begin{array}{l}\text { Use of the conventional preparation method in the area with intermediate and leveling } \\
\text { harrow and plowing. Area cleared by deforestation carried out } 20 \text { years ago, with the } \\
\text { cultivation of soy and corn. Adoption of soil correction practice annually with four tons } \\
\text { of limestone (PRNT } 75 \% \text { ) and mineral fertilizer } 300 \mathrm{~kg} \text { ha- } 1 \text { of NPK } 00-20-20 \text { and } 130 \\
\mathrm{~kg} \mathrm{ha}^{-1} \text { of } \mathrm{K}_{2} \mathrm{O} \text { in coverage. }\end{array}$ \\
\hline $\begin{array}{lr}\text { No-Tillage } & \text { System }+ \\
\text { Brachiaria as a cover } \\
\text { culture } \\
\text { adoption) }\end{array}$ & NTS+B2 & $\begin{array}{l}\text { Area cleared by deforestation done } 20 \text { years ago, with the adoption of no-tillage } \\
\text { planting in soybean cultivation and the use of Brachiaria as a cover crop with two years } \\
\text { of adoption, fertilized with simple superphosphate and potassium chloride in cover }\end{array}$ \\
\hline $\begin{array}{l}\text { Organic Vegetable } \\
\text { Growing System }\end{array}$ & OVGS & $\begin{array}{l}\text { Area under vegetable production with the application of tanned bovine manure and } \\
\text { crop rotation and green manure practices. The practices have been developed for } \\
\text { more than } 5 \text { years in the area under low soil mobilization. }\end{array}$ \\
\hline $\begin{array}{l}\text { Vegetable Cultivation + } \\
\text { No-Tillage }\end{array}$ & CVNT & $\begin{array}{l}\text { Area with vegetable cultivation carried out for more than } 10 \text { years with the adoption } \\
\text { of low soil mobilization practices and the adoption of no-till for } 7 \text { years. }\end{array}$ \\
\hline Cerrado Native Forest. & CNF & $\begin{array}{l}\text { Area under native vegetation in excellent condition of conservation, naturally virgin } \\
\text { and with no signs of anthropic change. }\end{array}$ \\
\hline
\end{tabular}

\section{Soil collections and sampling determinations}

The collections of the soil to different management and preparation systems of the areas at all depths $(0.0-0.05,0.05-0.10,0.10-0.20$, and $0.20-0.40 \mathrm{~m})$ were held in a deformed structure to determine the total organic C content ( TOC), organic soil matter (OSM) and light organic matter (LOM), using a drill-type auger, carrying out four simple samplings to compose a sample consisting of repetition and samples with the preserved structure for determining soil density (Ds) using a volumetric ring with three repetitions for each system and depth evaluated and their values used in determining the $\mathrm{C}$ and LOM stock.

The light organic matter was carried out by the method of physical densimetric fractionation by distilled water flotation using an adaptation of the method of Anderson et al. (1989). The levels of total organic carbon (TOC) determined by the wet oxidation method of organic matter, using a solution with an external heat source (YEOMANS et al., 1988). The soil organic matter content was calculated using the correction factor of 1.724 from the determination of the TOC values. And the soil density (Table 2) determined by the volumetric ring method, according to Embrapa. 
Table 2: Soil density (Ds) under different soil management systems and native cerrado forest at different depths of assessment.

\begin{tabular}{|c|c|c|c|c|}
\hline \multirow{2}{*}{ Management systems * } & \multicolumn{4}{|c|}{ Soil density $\left(\mathrm{Mg} \mathrm{m}^{-3}\right)$} \\
\hline & $0.0-0.05 \mathrm{~m}$ & $0.05-0.10 \mathrm{~m}$ & $0.10-0.20 \mathrm{~m}$ & $0.20-0.40 \mathrm{~m}$ \\
\hline CPS & 1.34 & 1.39 & 1.43 & 1.47 \\
\hline NTS+B2 & 1.32 & 1.34 & 1.35 & 1.36 \\
\hline OVGS & 1.24 & 1.24 & 1.27 & 1.28 \\
\hline CVNT & 1.29 & 1.30 & 1.32 & 1.32 \\
\hline CNF & 1.09 & 1.12 & 1.17 & 1.18 \\
\hline
\end{tabular}

*CPS: Conventional Planting System; NTS+B2: No-Tillage System + Brachiaria adoption for 2 years; OVGS: Organic Vegetable Growing System; CVNT: Cultivation of Vegetables under No-Tillage; and CNF: Cerrado Native Forest.

Posteriorly to the laboratory analyzes of density (Ds) and carbon content (TOC) the samples collected in the field were subjected to the measurement of the carbon stock $\left(\mathrm{Mg} \mathrm{ha}^{-1}\right)$ was calculated by multiplying the TOC $\left(\mathrm{g} \mathrm{kg}^{-1}\right)$, the density of the soil $\left(\mathrm{g} \mathrm{cm}^{-3}\right)$ and the thickness of the soil layer $(\mathrm{cm})$, according to the following equation (VELDKAMP, 1994):

$$
\mathrm{StkC}=\mathrm{TOC} * \mathrm{Ds} * \mathrm{e} / 10
$$

In which: StkC is the carbon stock in the analyzed layer ( $\left.\mathrm{Mg} \mathrm{ha}^{-1}\right)$; TOC is the total carbon content (\%); Ds is the apparent soil density of the analyzed layer $\left(\mathrm{g} \mathrm{cm}^{-3}\right)$; and, "e" is the layer thickness $(\mathrm{cm})$. The determination of LOM's stock followed the same procedure of determining the StkC, making substitutions when necessary.

The effects of different managements on soil quality attributes at different depths were submitted to analysis of variance with average values compared by Tukey's test $p<0.05$, with the aid of the statistical program Sisvar 5.6. it is because the practices to maintain and replace the straw into the soil surface might not be enough to keep the stability of the system.

\section{RESULTS AND DISCUSSION}

The variability observed for Light Organic Matter (LOM) was higher for soil more conservationist systems than the traditional cultivation system (Figure 1). For the same depth, LOM content differed statistically between the management systems, with the native forest having a broadly LOM contribution, followed by the vegetable cultivation system under no-tillage.
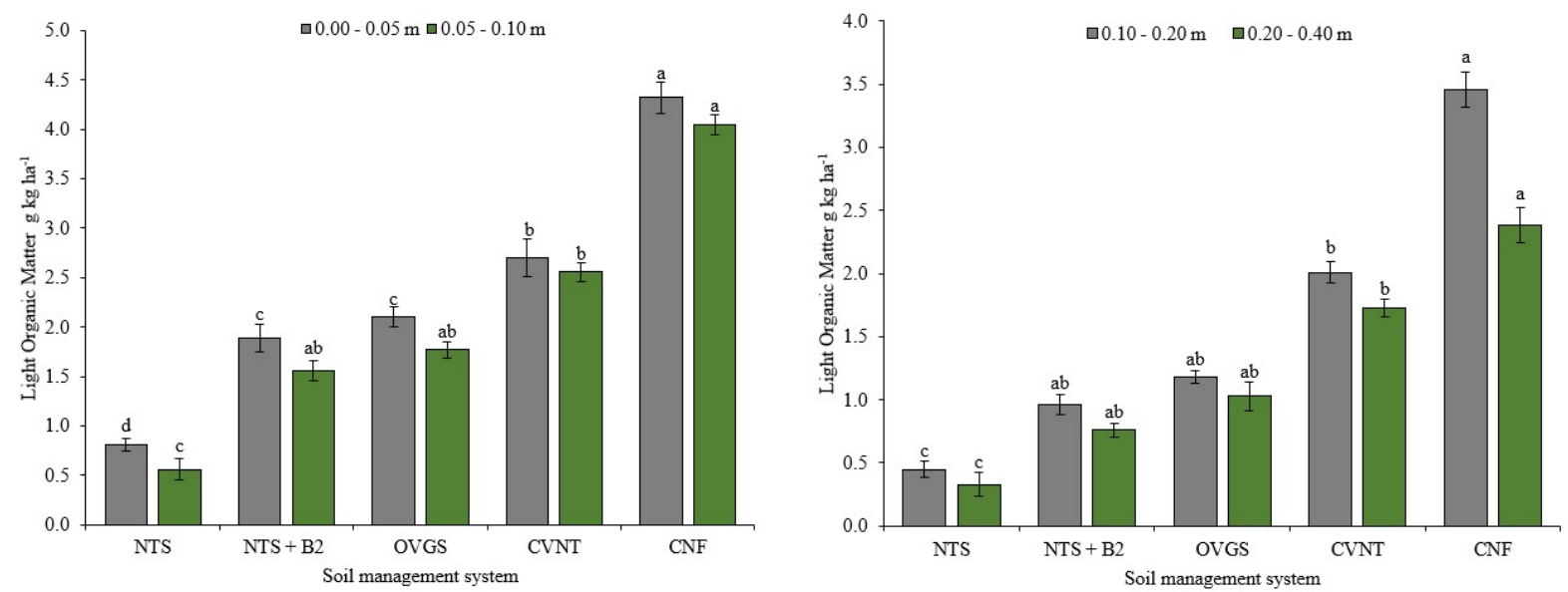

Figure 1: Light Organic Matter (LOM) in different soil management systems in the 0-5, 5-10, 10-20, and 20-40 cm layers. * NTS - No-Tillage System, NTS + B2 - No-Tillage System + Brachiaria with 2 years adoption, OVGS - Organic Vegetable Cultivation System, CVNT - Vegetable Cultivation + No-Tillage, CNF - Cerrado Native Forest. Means followed by the same letter do not differ, by Tukey's test $(p \leq 0.05)$. Bars represent the mean values $(n=3) \pm$ standard error of the mean. 
The difference in LOM content between conservationist systems must be nearly related to the quality of the plant material deposited in the soil in terms of the carbon and nitrogen input of the material. Noticeably, native areas hold a range of materials, from the most labile to recalcitrant ones, with the entry into the system carried out naturally, considering the environmental conditions. At the management system, this variability will depend on the type of material chosen and its $\mathrm{C} / \mathrm{N}$ ratio, as a consequence, it will condition variations in the decomposition rates in the medium. This may explain the lower content of LOM for the NTS+B2 system by attributing a low half-life of the residues on the soil surface, possibly due to a lower C/N ratio of the brachiaria.

In production systems, the mineralization of the residues disposed of soil is controlled, especially by the $\mathrm{C} / \mathrm{N}$ ratio, the quantity of lignin that ensures greater recalcitrance, the management practices adopted, and the abiotic environmental conditions linked to the climate factor that controls the variations of temperature and soil moisture and influence the activity of the decomposing microbiota, and this controls the LOM content that can be found in agricultural and natural areas. Also, even though soy is a crop with good adaptation in the no-tillage system, soybean farmers have found barriers for obtaining and maintaining a soil organic matter coverage (OMC) (FREITAS et al., 2016; SOUZA et al., 2016), a factor that can contribute to the reduction of LOM in these areas.

As shown in Figure 1, it was possible to verify that as the soil depth increased, there was a reduction in the LOM content in all systems. It is because, in more superficial layers, there is a direct deposition of residues, and this ensures a significant contribution in these layers, whereas, over time, a higher part of the material is incorporated into the soil in the form of LOM in-depth. However, its content tends to be smaller than in coverage due to elements related to decomposition. For Faccin et al. (2016), the highest quantity of LOM in the superficial layers of the soil results from the continuous and direct deposition of plant material on soil and the low anthropic influence, making the environment conducive to the maintenance of LOM.

The labile fractions of the soil's organic matter are constantly active, undergoing actions of microorganisms with accelerated dynamism, which highlights its importance for the maintenance of agricultural sustainability, due to its potential for nutrient cycling. However, it should be noteworthy that, additionally to the importance of the light fraction of organic matter as a sensitive indicator for the effect of changes in management practices, its quantification and relationship in the soil works as a way to predict the dynamics of organic matter in the soil and $C$ concentrations on the surface of these soils (WESEMAEL, 2019).

In an equivalent manner to the LOM content, the LOM stock (StKLOM) in the soil and its distribution along the depths differed statistically between the systems for the same evaluated layer (Figure 2). Both superficially $(0.0-0.05 \mathrm{~m}$ and $0.05-0.10)$ and in-depth $(0.10-0.20 \mathrm{~m}$ and $0.20-0.40)$ the StkLOM were higher $(p<0.05)$ for the CNF and the CVNT system compared to the other areas. Nevertheless, NTS+B2 and OVGS did not differ for all depths of assessment.

The largest StkLOM identified in the CNF and CVNT probably stems from a greater dynamic replacement of plant material on the soil for these environments. In native areas, the replacement process is constant, and the rate of incorporation along the soil profile depends on the natural bioturbation process 
of the soil biotic community. In CVNT systems, deposition is linked to the constant preservation needs of soil characteristics as well as of humidity and thermal control to reduce water loss and ensure greater availability of it for horticultural crops. Moreover, with the adoption of adequate management, it is possible to ensure greater productivity even than in the condition of family farming. Besides, the CVNT system has a longer implantation time than NTS+B2 and the production area because it is a family farming vegetable crop that is relatively smaller than the soybean production areas. This influences the management and the process of maintaining the soil cover, reducing or increasing the mineralization rate of this labile fraction according to the management employed and changing its stocks in the soil.
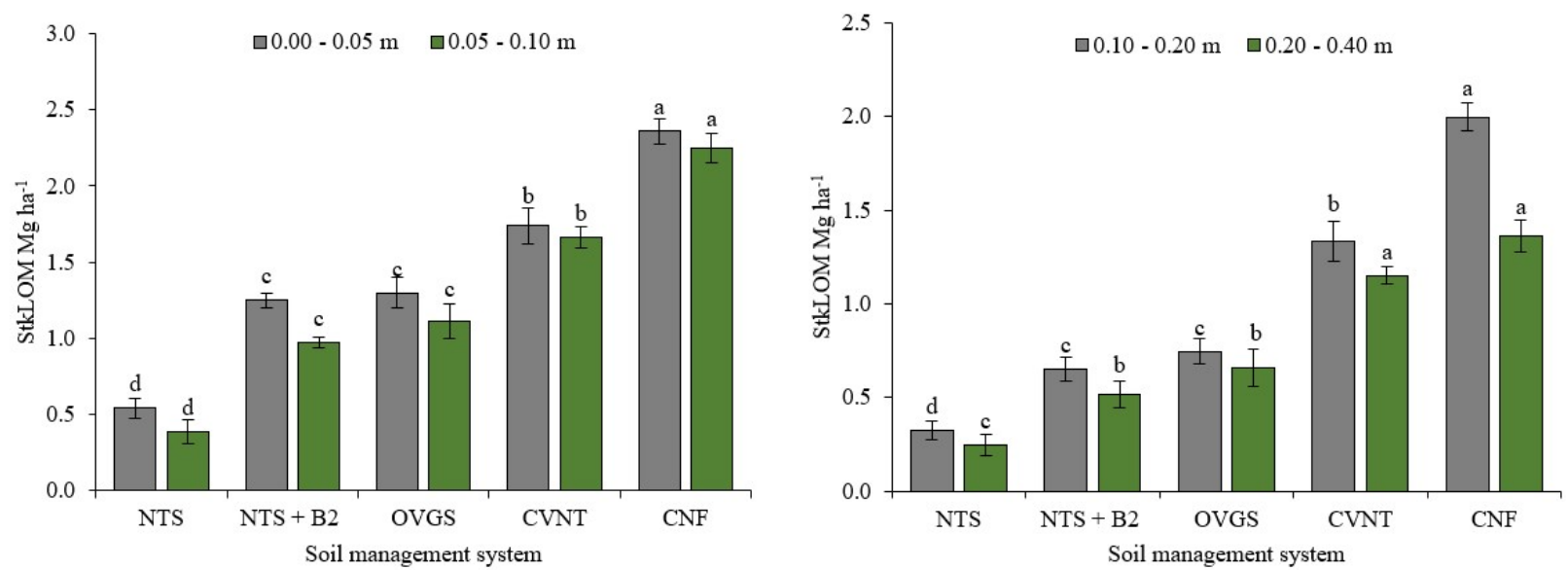

Figure 2: Stock of Light Organic Matter (StkLOM) in different soil management systems in the 0-5, 5-10, 10-20, and 20-

$40 \mathrm{~cm}$ layers. * NTS - No-Tillage System, NTS + B2 - No-Tillage System + Brachiaria with 2 years adoption, OVGS Organic Vegetable Cultivation System, CVNT - Vegetable Cultivation + No-Tillage, CNF - Cerrado Native Forest. Means followed by the same letter do not differ, by Tukey's test $(p \leq 0.05)$. Bars represent the mean values $(n=3) \pm$ standard error of the mean.

According to Naresh et al. (2017), among the labile fractions of OSM is LOM derived in any case from organic materials recently incorporated into the soil. This fraction has fast turnover rates and responds quickly to soil management intervention compared to more stable OSM in the system (LOUIS et al., 2016).

It should also be noted that the variability and distribution of the LOM stock content along the soil profile depend in any case on the depth, soil class, and type of vegetation, as they influence the chemical reactions on light fraction and its thermal stability. Soucémarianadina et al. (2019), in a study of the heterogeneity of the chemical composition of this labile fraction from OSM, found that successive variations in the chemistry of the light particulate fraction linked to the $\mathrm{C} / \mathrm{N}$ ratio and its functional groups and increased thermal stability with depth suggested different sources of input for the superficial and deep layers of soil and an increase in biogeochemical stability in deep layers of soil.

TOC contents differed statistically between the soil management systems and the area hold under natural vegetation (Figure 3) with their highest contents identified in the areas of CNF, OVGS, and CVNT for the superficial depths. In any case, as they are systems affected by low soil mobilization and because they are subjected to management of organic matter increment through direct organic fertilization or cover residues, such results are consequently expected. 

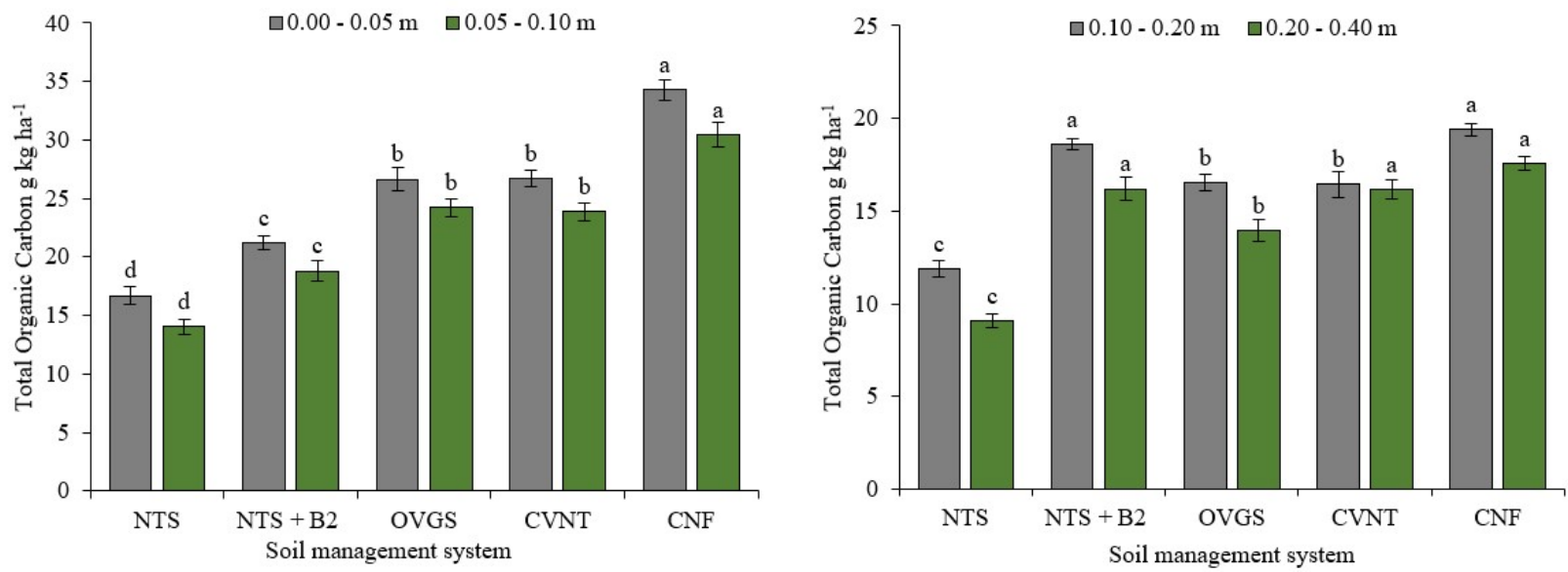

Figure 3: Total Organic Carbon (TOC) in different soil management systems in the 0-5, 5-10, 10-20, and 20-40 cm layers.* NTS - No-Tillage System, NTS + B2 - No-Tillage System + Brachiaria with 2 years adoption, OVGS - Organic Vegetable Cultivation System, CVNT - Vegetable Cultivation + No-Tillage, CNF - Cerrado Native Forest. Means followed by the same letter do not differ, by Tukey's test $(p \leq 0.05)$. Bars represent the mean values $(n=3) \pm$ standard error of the mean.

Vegetable production areas have a considerable replacement of surface plant material from green manure and the use of bovine manure, which significantly contributes to the $\mathrm{C}$ supply in the system (Figure 3). This is in line with findings by Lugato et al. (2014) that in simulation tests using models verified that the use of green manure results in higher $\mathrm{C}$ storage in the soil in a more lasting projection. Moreover, Jiang et al. (2018), claimed that the use of organic waste with narrow $\mathrm{C} / \mathrm{N}$ ratios, such as bovine manure is more efficient in increasing TOC compared to the incorporation of straw, as in NTS+B2.

The TOC contents decreased significantly with the increase of the depth of the soil for all the management systems and CNF being the highest values in depth observed in the NTS+B2, CVNT, and CNF. These results are corroborated by several studies (HOBLEY et al., 2015) with the TOC concentration decreasing in depth. According to Li et al. (2016), there is a relationship between TOC and depth, and this can be described using a regression function $(r=-0.720)$, because in general, as the depth increases, the $C$ content tends to be reduced. Similarly, Wang et al. (2017), found that the TOC concentration and depth could also be well described by the power function ( $R 2>0.9$ ). Furthermore, the content of $C$ depends on the balance of $\mathrm{C}$ inputs and outputs in soils, and its profile distribution is generally influenced by the vertical distribution of the root system of crops (LI et al., 2016).

The low TOC values in the CPS (Figure 3 ) are justified by the management and conventional tillage of the soil, that through weight mechanization and a high degree of plowing of the soil helps to intensify the process of mineralization of organic residues both in more layers shallow and in-depth. Wesemael (2019) states that soils subjected to agricultural production lose a large part of their organic matter because of the imbalance between the reduction of $\mathrm{C}$ entry in the system (due to the export of crops) and the increase in $\mathrm{C}$ losses due to decomposition after disturbance by plowing. For this reason, there has been a great search for more conservationist agriculture, aiming to increase the input and reduce the output of $C$ in these environments. Thus, the maintenance of OSM is one of the objectives of conservation agriculture, resulting in better soil functions, such as greater water retention and, mainly, in poor soils in OM (WESEMAEL, 2019).

Despite the relevance given the observations of the TOC as an indicator of soil quality, it is worth 
stressing that in some situations, the TOC may not work as an efficient indicator to describe the impacts of land-use changes in a short time. Several studies have been shown that modifications in TOC occur over a longer period, usually around three to five years after the change in the management system (PRASAD et al., 2015).

For OSM levels after statistical analysis of the variable, it was noted that OSMt treatments differed statistically for a given depth (Figure 4). According to the dynamics of the other variables analyzed, the areas under horticultural cultivation obtained the highest percentages of OSM slightly. Only CNF showed higher values for this parameter, while in-depth, the OSM content was similar between NTS+B2 and CNF. When analyzing the results, it is noticed that the type of management and residues used in the cultivation areas directly influenced the dynamics of OSM. It is presumably as a function of the type of plant material added to the soil, such as those of low LOMecular weight more easily decomposed.

Salton et al. (2011) report that the quality of the OSM has an intrinsic relationship with the variability and distribution of its fractions in the soil and therefore causes different effects on the edaphic properties. In the soil, it works as an important pointer of the effects of use and the various systems adopted, in which the determination of TOC helps in the detection of changes caused by soil quality.
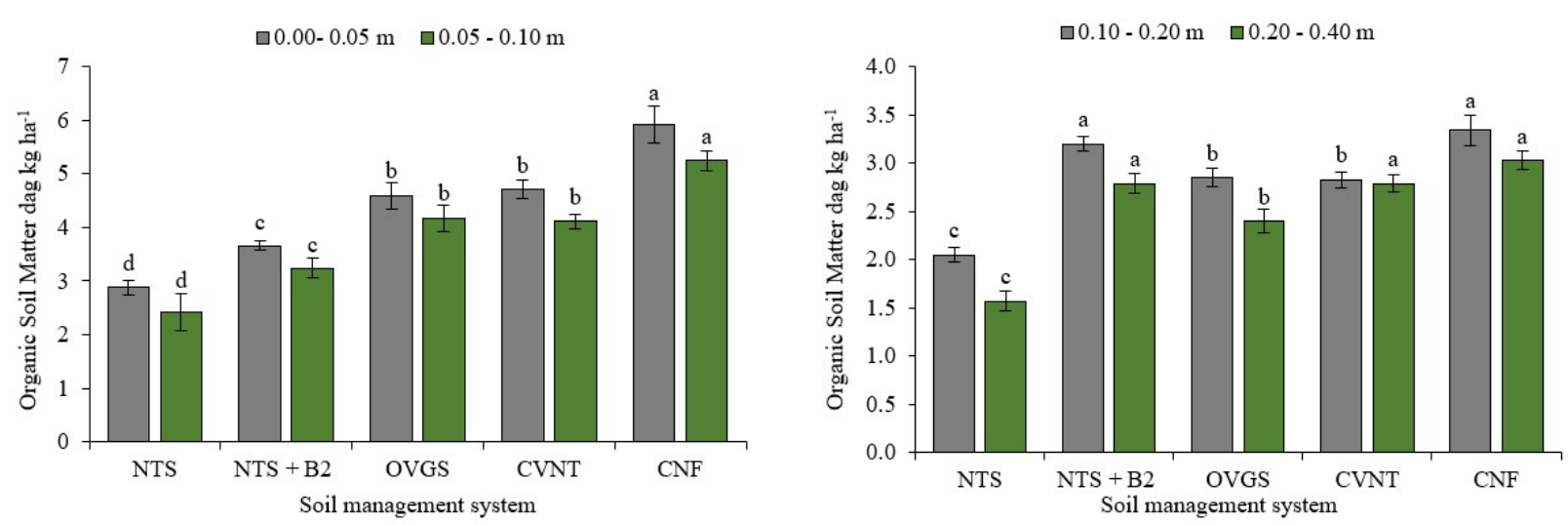

Figure 4: Organic Soil Matter (OSM) in different soil management systems in the 0-5, 5-10, 10-20 and 20-40 cm layers. * NTS - No-Tillage System, NTS + B2 - No-Tillage System + Brachiaria with 2 years adoption, OVGS - Organic Vegetable Cultivation System, CVNT - Vegetable Cultivation + No-Tillage, CNF - Cerrado Native Forest. Means followed by the same letter do not differ, by Tukey's test $(p \leq 0.05)$. Bars represent the mean values $(n=3) \pm$ standard error of the mean.

The higher content of in-depth OSM for NTS+B2 may be related to the short time of adoption of the soybean no-tillage system, since many studies report that as the both TOC and OSM depth increased, suffers a decrease, a fact contrary to this study. However, OSM serves as a parameter to evaluate production systems and their sustainability in terms of maintaining soil quality. According to Robinson et al. (2013), in tropical and subtropical soil conditions, the TOC management presents complex interactions with the characteristics and properties of the soil, where the OSM is located, influencing the ecosystem services of this system. For issues like these that the maintenance and preservation of soil ecosystem services, that the environment dynamics is very considerable, it becomes a priority in the development of conservationist agricultural areas, in which organic management provides a wider range of ecosystem services compared to traditional crop management (REGANOLD et al., 2016). 
Furthermore, compared to the results observed in this study, Dorneles et al. (2015), studying the dynamics of OSM with a ten-year experiment at different depths $(0-5,5-10$ and $10-20 \mathrm{~cm})$ found in three different management systems (conventional system, system with reduced turning and planting system direct), variations in the OSM content in the OSMt superficial layers. The authors assert that such variations start to be measurable after the 40th month, having their peak at the 80th month of the system's implantation, showing the effects of the different managements.

The idea of seeking food security in the world has highlighted the adoption of agricultural practices with low environmental impacts, which contribute to the mitigation of greenhouse gas emissions and reduce the processes of soil erosion, as well as the nutrients losses (NODARI et al., 2015). Also, in these practices, the management of low soil, cultivation under straw cover, and alternative use of organic fertilizers is inserted

In studies conducted by Carvalho et al. (2014), when seeking to increase C sequestration is extremely important, especially those carried out in Cerrado areas due to the increasing speed of loss of native vegetation. Nutrient recovery and cycling in these areas through the adoption of conservationist systems, such as no-till system (NTS) and others represent an alternative low-carbon agriculture route and assist in the revitalization of previously infertile areas for agricultural use (CARVALHO et al., 2014).

Regarding the StkC in the soil, similar results were observed in the OSM, there was, in general, greater C storage in the soil for the systems of low soil mobilization, responsible for adopting more conservationist practices.

In all cases assessed, the StkC of the management systems differed statistically within the same layer (Figure 5), increasing with depth. However, in the more superficial layers, the CNF presented the highest StkC, followed by the OVGS and CVNT systems, with the lowest StkC in the areas of NTS+B2 and CPS, respectively. Diferentemently, when observing the increase in StkC with depth, it was noted that the NTS + B2 showed the highest results compared to the other systems, and the CPS had less storage of soil carbon.
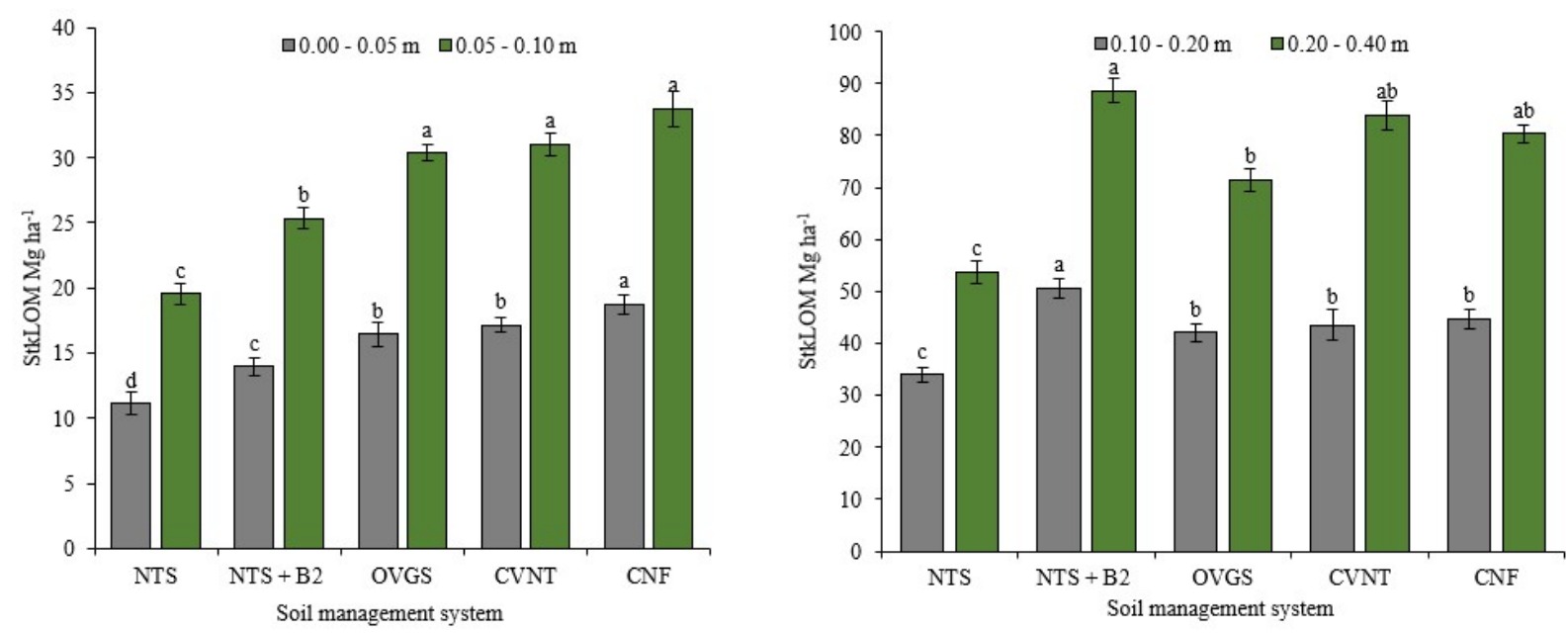

Figure 5: (StkLOM) in different soil management systems in the 0-5, 5-10, 10-20, and 20-40 cm layers. * NTS - NoTillage System, NTS + B2 - No-Tillage System + Brachiaria with 2 years adoption, OVGS - Organic Vegetable Cultivation System, CVNT - Vegetable Cultivation + No-Tillage, CNF - Cerrado Native Forest. Means followed by the same letter do not differ, by Tukey's test $(p \leq 0.05)$. Bars represent the mean values $(n=3) \pm$ standard error of the mean. 
The lower storage of $\mathrm{C}$ of NTS+B2 in the superficial layers may be related to rapid mineralization of organic matter in the soil in these areas, reducing the $C$ content stored at depths $0.0-0.05$ and $0.05-0.10$, promoting a significant increase with a higher depth (Figure 2) associated with the contribution of brachiaria as a cover culture due to its composition and rapid mineralization. Besides, the short-time of adopting no-till can contribute to these results; it is because the practices to maintain and replace the straw into the soil surface have been not enough to keep the stability of the system, and thus increasing the decomposition rates of the material. Pires et al. (2008) point out that the effectiveness of NTS depends on several factors, especially the quantity and quality of plant residues, possibly being the great challenge of agricultural sustainability in Cerrado regions.

In this case, it is believed that the elevation of the StkC in the deeper layers may be further linked to the quality of the organic material to be degraded than to the quantity of material produced in the different layers; it can assure a longer permanence of $C$ in a system in detriment of the other. Besides, the greater density of the soil in the NTS+B2 (Table 2) compared to the other low soil mobilization systems also contributed to these results. Calonego et al. (2012), in a study of the StkC and physical attributes of the soil under different management systems, observed that more compact areas and with low vegetation cover had direct implications on the density of the soil and other attributes and, concomitantly in the StkC. Also, Assad et al. (2013) state that several studies report that many variables control C stocks in the soil. On a regional scale, climatic variables, such as temperature and rainfall, have significant importance, and locally inherent properties in the soil, such as density and natural fertility, are stand out.

It is noted that the lower StkC values in the CPS area, compared to other ones (Figure 2), are due to the higher soil mobilization in this type of management system, this contributes to the increase in the OSM mineralization by the disruption of the aggregates and its exposure to the action of microorganisms, and consequently, compromising the stability of OSM. Thus, areas with low soil mobilization there is an inverse pattern to this dynamic, so that crop rotation, organic fertilization, and the maintenance of plant residues on the surface contribute to increasing the $\mathrm{C}$ content and promote their better interaction with the mineral phase of the soil, which, consequently, increases the stability of aggregates (MELO et al., 2016).

For these results, it becomes evident that the process of change in the use of land linked to different soil management practices promotes changes in the soil $\mathrm{C}$ dynamics, especially regarding the input and output relationships of this component to the system (PRIMIERI et al., 2017). Thus, variations in StkC in the soil are associated with management, which can cause both increases and decreases in this element (BRITO et al., 2018) and also interfere with the other chemical attributes of the soil (ROSSET et al., 2014)

\section{CONCLUSIONS}

The content, dynamics, and maintenance of $\mathrm{C}$ in the soil are strictly influenced by the management system adopted, both for the lighter fractions of organic matter and for the more mineralized forms such as TOC, OSM, and StkC. The adoption of management systems of low soil mobilization in production areas of annual and horticultural crops contributes to the maintenance of $\mathrm{C}$ in the soil. Conservation systems ensure 
a greater $\mathrm{C}$ supply along with soil profile, and the use of cover materials such as Brachiaria in no-tillage contributes to an increase in carbon in depth.

\section{REFERENCES}

ANDERSON, J. M.; INGRAM, J. S. I.. Tropical soil biology and fertility: a handbook of methods. Wallingford: $C A B$ International, 1989.

ANDRADE JUNIOR, A. S.; BASTOS, E. A; SILVA, C. O.; GOMES, A. A. N.; FIGUEREDO JÚNIOR, L. G. M.. Atlas Climatológicas do Estado do Piauí. Teresina: Embrapa Meio- Norte, 2004.

ASSAD, E. D.; PINTO, H. S.; MARTINS, S. C.; GROPPO, J. D.; SALGADO, P. R.; EVANGELISTA, B.; VASCONCELLOS, E.; SANO, E. E.; PAVÃO, E.; LUNA, R.; CAMARGO, P. B.; MARTINELLI, L. A.. Changes in soilcarbon stocks in Brazilduetoland use: paired site comparisonsand a regional pasturesoilsurvey. Biogeosciences, v.10, p.6141-6160, 2013.

BRITO, M. R.; SIQUEIRA, F. L. T.; SOUSA, I. J. A.; SOUSA, R. N. Estoque de carbono no solo sob diferentes condições de Cerrado. Revista Desafios, v.5, p.114-124, 2018.

CALONEGO, J. C.; SANTOS, C. H.; TIRITAN, C. S.. Estoques de carbono e propriedades físicas de solos submetidos a diferentes sistemas de manejo. Revista Caatinga, v.25, n.2, p.128-135, 2012.

CARVALHO, J. L. N.; RAUCCI, G. S.; FRAZÃO, L. A.; CERRI, C. E.; BERNOUX, M.; CERRI, C. C.. Crop-pasturerotation: A strategy to reduce soil Greenhouse gas emissions in the Brazilian Cerrado. Agriculture, Ecosystems and Environment, v.183, p.167-175, 2014.

CASTRO, A. S.. Evolução temporal do uso da terra no município de ForOSMa do Rio Preto/Bahia. Dissertação (Mestrado em Geografia) - Universidade de Brasília, Brasília, 2012.

DORNELES, E. P.; LISBOA, B. B.; ABICHEQUER, A. D.; BISSANI, C. A.; MEURER, E. J.; VARGAS, L. K.. Tillage, fertilization systems and chemical attributes of a Paleudult. Scientia Agricola, v.72, n.2, p.175-186, 2015.

FACCIN, F. C.; MARCHETTI, M. E.; SERRA, A. P.; ENSINAS, S. C.. Frações granulométricas da matéria orgânica do solo em consórcio de milho safrinha com capim-marandu sob fontes de nitrogênio. Pesquisa Agropecuária Brasileira, Brasília, v.51, n.12, p.2000-2009, 2016.

FREITAS, M. E.; SOUZA, L. C. F.; SALTON, J. C.; SERRA, A. P.; MAUAD, M.; CORTEZ, J. W.; MARCHETTI, M. E.. Croprotationaffectssoybean performance in no-tillage system underoptimalanddrycroppingseasons. Australian Journal of Crop Science, v.10, p.353-361, 2016. DOI: http://doi.org/10.21475/ajcs.2016.10.03.p7177

HOBLEY, E.; WILSON, B.; WILKIE, A.; GRAY, J.; KOEN, T.. The drivers of soil organic carbon storage and vertical distribution in eastern Australia. Plant Soil, v.390, p.111-127, 2015.

JIANG, G.; ZHANG, W.; XU, M.; KUZYAKOV, Y.; ZHANG, X.; WANG, J.; DI, J.; MURPHY, D. V.. Manure and mineral fertilizers Effects on crop yield and soil carbon sequestration: a meta-analysis and modeling Across China. Global Biogeochemical Cycles, v.32, p.1659-1672, 2018.

KHORRAMDEL, S.; KOOCHEKI, A.; MAHALLATI, M. N.; KHORASANI, R.; GHORBANI, R.. Evaluation of carbon sequestration potential in corn fields with different management systems. Soil \& Tillage Research, v.133, p.2531, 2013.

LEITE, L. F. C.; GALVÃO, S. R. S.; HOLANDA NETO, M. R.; ARAÚJO, F. S.; IWATA, B. F.. Atributos químicos e estoques de carbono em Latossolo sob plantio direto no cerrado do Piauí. Revista Brasileira de Engenharia Agrícola e Ambiental, v.14, p.1273-1280, 2010.

LI, L. J.; BURGER, M.; DU, S. L.; ZOU, W. X.; VOCE, W. Y.; HAO, X. X.; LU, X. C.; ZHENG, L.; HAN, X. Z.. Change in soil organic carbon between 1981 and 2011 on agricultural land in Heilongjiang Province, northeastern China. Journal of the Science of Food and Agriculture, v.96, p.1275-1283, 2016.

LOUIS, P. B.; MARON, P.; VIAUD, V.; LETERME, P.; MENASSERI-AUBRY, S.. Soil C e $\mathrm{N}$ modelos que integram a diversidade microbiana.

Environmental Chemistry Letters, v.14, n.3, p.331-344, 2016.

LUGATO, E.; BAMPA, F.; PANAGOS, P.; MONTANARELLA, L.; JONES, A.. Potential carbon sequestration in European farmland is estimated by modeling a comprehensive set of management practices. Global Mude Biology, v.20, p.35573567, 2014.

MELO, G. B.; PEREIRA, M. G.; PERIN, A.; GUARESCHI, R. F.; SOARES, P. F. C.. Estoques e frações da matéria orgânica do solo sob os sistemas plantio direto e convencional de repolho. Pesquisa Agropecuária Brasileira, v.51, n.9, p.15111519, 2016.

NARESH, R. K.; TIMSINA, J.; BHASKAR, V.; GUPTA, R. K.; SINGH, A. K.; DHALIWA, S. S.; RATHORE, R. S.; KUMAR, V.; SINGH, P.; SINGH, S. P.; TYAGI, S.; KUMAR, S.; MAHAJAN, C. N.. Effects of crop, residue and nutrient management on soil organic carbon dynamics and their fractions, soil aggregate stability and soil carbon sequestration: a review. Nutrition Economics, v.12, n.2, p.53-80, 2017.

NODARI, R. O.; GUERRA, M. P.. A agroecologia: estratégias de pesquisa e valores. Estudos Avançados, v.29, n.83, p.183207, 2015.

PAUL, B. K.; VANLAUWE, B.; AYUKE, F.; GASSNER, A.; HOOGMOED, M.; HURISSO, T. T.; KOALA, S.; LELEI, D.; NDABAMENYE, T.; SIX, J.; PULLEMAN, M. M.. Medium-term impact of tillage and residue management on soil aggregate stability, soil carbon and crop productivity. Agriculture, Ecosystems and Environment, v.164, p.14-22, 2013.

PIRES, F. B.; ASSIS, R. L.; PROCÓPIO, S. O.; SILVA, G. P.; 
MORAES, L. L.; RUDOVALHO, M. C.; BÔER, C. A.. Manejo de plantas de cobertura antecessoras à cultura da soja em plantio direto. Ceres, v.55, n.2, p.094-101, 2008

PRASAD, J. V. N. S.; SRINIVASA, R. A. O.; SRINIVAS, K.; NAGA JYOTHI, C. H.; VENKATESWARLU, B.; RAMACHANDRAPPA, B. K.; DHANAPAL, G. N.; RAVICHANDRA, K.; MISHRA, P. K.. Effect of ten years of reduced tillage and recycling of organic matter on crop yields, soil organic carbon and its fractions in Alfisols of semi arid tropics of southern India. Soil and Tillage Research, v.156, p.131-139, 2016.

PRIMIERI, S.; MUNIZ, A. W.; LISBOA, H. M.. Dinâmica do Carbono no Solo em Ecossistemas Nativos e Plantações Florestais em Santa Catarina. Floresta e Ambiente, v.24, p.19, 2017.

REGANOLD, J. P.; WATCHER, J. M.. Organic agriculture in the twenty-first century. Nature Plants, v.2, p.8, 2016.

ROBINSON, D. A.; HOCKLEY, N.; COOPER, D. M.; EMMETT, B. A.; KEITH, A. M.; LEBRON, I.; REYNOLDS, B.; TIPPING, E.; TUE, A. M.; WATTS, C. W.; WHALLEY, W. R.; BLACK, H. I. J.; WARREN, G. P.; ROBINSON, J. S.. Natural capital and ecosystem services, developing an appropriate soils framework as a basis for valuation. Soil Biology Biochemistry, v.57, p.1023-1033, 2013.

ROSSET, J. S.; SCHIAVO, J. A.; ATANÁZIO, R. A. R.. Atributos químicos, estoques de carbono orgânico total e das frações humificadas da matéria orgânica do solo em diferentes sistemas de manejo de cana-deacúcar. Semina: Ciências Agrárias, v.35, n.5, p.2351-2366, 2014

SALTON, J. C.; MIELNICZUK, J.; BEYER, C.; FABRÍCIO, A. C.; MACEDO, M. C. M.; BROCH, D. L.. Teor e dinâmica do carbono no solo em sistemas de integração lavoura pecuária. Pesquisa Agropecuária Brasileira, v.46, n.10, p.13491356, 2011.
SOUCÉMARIANADINA, L.; CÉCILLONA, L.; CHENUC, C.; BAUDIND, F.; NICOLASE, M.; GIRARDINC, C.; DELAHAIEA, A.; BARRÉA, P.. Heterogeneity of the chemical composition and thermal stability of particulate organic matter in French forest soils. Geoderma, v.342, p.65-74, 2019.

SOUZA, L. C. F.; FREITAS, M. E.; LOURENTE, E. R. P.; SERRA, A. P.; RECH, J.; FROTA, F.; LOUREIRO, G. E. S.. The effects of crop rotation systems on maize agronomic traits under notillage in optimal and dry cropping seasons. African Journalof Agricultural Research, v.11, p.2369-2377, 2016. DOI: $\underline{\text { http://doi.org/10.5897/AJAR2016.11179 }}$

TEIXEIRA, L.; LA SCALA JÚNIOR, N.; LOPES, A.. Fluxo de CO2 do solo após aração e escarificação em diferentes condições. Holos Environment, v.10, p.1-11, 2010.

VARGAS, R.; RANGEL, O. J. P.. Indicadores de qualidade do solo em agroecossistemas. Revista Brasileira de Gestão Ambiental, v.7, n.1, p.102-129, 2013.

VELDKAMP, E.. Organic Carbon Turnover in Three Tropical Soils under Pasture after Deforestation. Soil Science Society of America Journal, v.58, p.175-180, 1994.

WANG, Q.; SONG, J.; CAO, L..; LI, X; YUAN, H.; LI, N.. Distribution and storage of soil organic carbon in a coastal wetland under the pressure of human activities. Journal of Soils and Sediments, v.17, p.11-22, 2017.

WESEMAEL, B.; CHARTIN, C.; WIESMEIER, M.; VON LÜTZOW, M.; HOBLEY, E.; CARNOL, M.; KÖGEL-Knabner, I.. Um indicador da dinâmica da matéria orgânica em solos agrícolas temperados. Agricultura, Ecossistemas e Meio Ambiente, v.274, p.62-75, 2019.

YEOMANS, J. C.; BREMNER, J. M.. A rapid and precise method for routine etermimation of organic carbon in soil. Communications in Soil Science Plant Analysis, v.19, p.1467-1476, 1988.

A CBPC - Companhia Brasileira de Produção Científica (CNPJ: 11.221.422/0001-03) detém os direitos materiais desta publicação. Os direitos referem-se à publicação do trabalho em qualquer parte do mundo, incluindo os direitos às renovações, expansões e disseminações da contribuição, bem como outros direitos subsidiários. Todos os trabalhos publicados eletronicamente poderão posteriormente ser publicados em coletâneas impressas sob coordenação da Sustenere Publishing, da Companhia Brasileira de Produção Científica e seus parceiros autorizados. Os (as) autores (as) preservam os direitos autorais, mas não têm permissão para a publicação da contribuição em outro meio, impresso ou digital, em português ou em tradução. 